\title{
A STUDY ON UNDER GROUNDWATER POLLUTION AT NAMAKKAL DISTRICT, TAMILNADU, INDIA
}

\author{
Vignesh P. $\mathbf{N}^{1}$, Vinothkumar $\mathbf{M}^{2}$ \\ ${ }^{1} P G$ Scholar, Knowledge Institute of Technology, Salem, India \\ ${ }^{2}$ Asst.proffessor, Department of Mechanical Engineering, Knowledge Institute of Technology, Salem, India
}

\begin{abstract}
Due to the monsoon changes and the failure of rainfall the drinking water scarcity become the most important problem. The groundwater is one of the most important sources for drinking water nowadays. However due to the dumping of municipal wastes and agricultural wastes in to the ground and industrial waste water into the river leads to the contamination of groundwater. Thus the analysis of the groundwater quality is very important to protect the human health. So in this study an assessment of groundwater quality is conducted in and around Namakkal district, Tamilnadu, India. About twenty samples were taken from the wells and bore wells throughout the Namakkal district with necessary precaution and the physico-chemical and biological characteristics are analyzed.
\end{abstract}

Keywords: water quality, groundwater contamination, drinking water, total dissolved solids.

\section{INTRODUCTION}

About seventy percentage of the earth is surrounded by water. But it is not suitable for drinking, so here is the actual drinking water scarcity problem will occurs. Groundwater is the only source for drinking water, but due to the discharge of industrial waste water in to the river without treating it properly it will contaminate the groundwater. The dumping of agricultural wastes and municipal wastes are also play an important role on contaminating the groundwater.

Groundwater is an important water resource for domestic and agriculture in both rural and urban parts of India(Mohamed Hanipha and ZahirHussian, 2013). But people are not aware of diseases caused due to water contamination. Drinking water with good quality is very important to improve the life of people and prevent disease(Adewoya and Oludura, 2007).

Namakkal district is start functioning as a separate district from 01-01-1997. It is separate from Salem district. The geographical area of the Namakkal district is of about 3363 sq.km. It lies between $11^{\circ} 13^{\prime} 8.4^{\prime \prime N}$ North latitudes and $78^{\circ} 10^{\prime} 1.2^{\prime}$ 'East longitudes. Namakkal district is surrounded by Salem and Trichy on the eastern side, erode on western side, Salem on northern side, Karur on southern side. The northern sides of the Namakkal district are mountains and the southern sides are plain areas.

Agriculture is the important occupation of the people. Lorry body building industries is also a landmark for Namakkal district. The northeast monsoon and southwest monsoon gives rainfall to this district. The rivers in this district are Aiyaru, Cauvery, Karipottan Aaru and Thirumanimutharu. Dug wells and bore wells provides drinking water when compared to other sources.
Hence the assessment of the groundwater quality is carried out in order to find out the contaminants that present in the drinking water. The parameters such as electrical conductivity, pH, alkalinity, total hardness, Calcium, magnesium, sodium, potassium, iron, manganese, chloride, fluoride, ammonia, sulphate, phosphate and nitrate are analyzed and compared with WHO. (1992) standards.

\section{SAMPLES AND METHODS}

The samples were taken all around the Namakkal district. About twenty places were chosen and are named as Area1 to Area20 (A1-A20). The Areasare Atthanoor (A1), Vennandur (A2), Gurusamypalayam (A3), Vaiyappamalai (A4), Elachipalayam (A5), Thiruchengode (A6), Malasamuthiram (A7), Pallippalayam (A8), Mohanur (A9), Paramathi (A10), Velur (A11), Erumapatty (A12), Namakkal (A13), Sendhamangalam (A14), Bellukurichy (A15), Rasipuram (A16), Namagiripet (A17), Mettala (A18), Aayilpatty (A19) andmangalapuram (A20).

The samples are collected in a 1000ml plastic container with necessary precautions and they are properly sealed and send to the laboratory for analysis as per APHA. (1995) standards

\section{RESULTS AND DISCUSSIONS}

The results obtained from samples are tabulated in table-1. The obtained results are then compared with the WHO standards and discussed.

\subsection{Electrical Conductivity (EC)}

The electrical conductance value of all the samples varies in the range of 124 to $4970 \mathrm{micro} \mathrm{mho} / \mathrm{cm}$. The maximum electrical conductivity value of (4970 micro $\mathrm{mho} / \mathrm{cm}$ ) was found in the Area (A15) and the minimum value of (124 micro $\mathrm{mho} / \mathrm{cm}$ ) was found in the Area (A20).The electrical 
conductance is a good indication of total dissolved solids which is a measure of salinity that affects the taste of portable water (Pradeep Jain, 1998). The electrical conductivity is also influenced by ionic mobility, ionic valence and temperature (Mohamed Hanipha and ZahirHussian, 2013).

\subsection{Total Dissolved Solids (TDS)}

The total dissolved solids in water are due to the presence of sodium, potassium, calcium, magnesium, manganese, carbonates, bicarbonates, chlorides, phosphates, organic matters and other particles (Bhattachary et al., 2012). The value of the total dissolved solids of all samples varies in the range of 87 to $3479 \mathrm{mg} / \mathrm{l}$. The maximum value was obtained at the Area (A15) and the minimum value was obtained at the Area (A20). The maximum allowable limit of total dissolved solids in groundwater for domestic purpose is 1500mg/l WHO. (1992). According to the classification of drinking water on the basics of TDS values, the AREA (A15) is found to be moderately saline, the Areas (A1, A2, A3, A5, A7, A8, A9, A10, A11, A12, A13,A16,A17\&A18) are found to be slightly-saline and the Areas (A4, A6, A14, A19 \&A20) are found to be non-saline.

\section{$3.3 \mathrm{pH}$}

The purpose of finding the $\mathrm{pH}$ value is to determine whether the drinking water is acidic or alkaline in nature. The $\mathrm{pH}$ value of the samples varies in the range of 6.78 to 7.98. The maximum value of $\mathrm{pH}$ was obtained at the Area (A1), and the minimum value of the $\mathrm{pH}$ was obtained at the Area (A19). The permissible amount of the $\mathrm{pH}$ value in the groundwater is 7.0 to 8.5. The Areas (A5, A10, A20, A13, $\mathrm{A} 3, \mathrm{~A} 8 \mathrm{\&}$ A19) the $\mathrm{pH}$ value is less than the permissible limit it showed that they are of alkaline in nature. If the $\mathrm{pH}$ value lies beyond the limit it affects the mucous membrane of the cells(KoulNishtha et al., 2012).

\subsection{Calcium (Ca)}

Calcium is an essential nutrition element for human being and aids in maintaining the structure of plant cells and soils(Chari and Lavanya, 1994).The value of calcium of all the samples varies in the range of 8 to $292 \mathrm{mg} / \mathrm{l}$. The maximum value of the calcium was obtained at the Area (A15), and the minimum value of the calcium was obtained at the Area (A20). The Areas (A3, A8, \& A15) the values are found to be greater than the permissible limit $(200 \mathrm{mg} / \mathrm{l})$.

\subsection{Magnesium (Mg)}

The magnesium value of all the samples varies in the range of 4 to $168 \mathrm{mg} / \mathrm{l}$. The maximum value of magnesium was obtained at the Area (A15), and the minimum value of the magnesium was obtained at the Area (A20). The permissible limit of the magnesium value in the groundwater is $150 \mathrm{mg} / \mathrm{l}$ according to the WHO standards. All the Areas other than the Area (A15) are lies in the permissible limit. Magnesium generally occurs in lesser concentration than calcium because of dissolution of magnesium rich mineral is slow process and calcium is more abundant in earth crust (Varadarajan et al., 2012).

\subsection{Sodium (Na)}

Sodium and potassium are the most important minerals occurring naturally in the groundwater. These two elements are directly added into the groundwater from industrial and domestic wastesand contribute salinity of water(Chari and Lavanya, 1994). The sodium value of all the samples varies in the range of 12 to $544 \mathrm{mg} / \mathrm{l}$. the maximum value of the sodium was obtained at the Area (A15), and the minimum value was obtained at the Area (A20). The permissible limit of sodium value in the groundwater is $200 \mathrm{mg} / \mathrm{l}$ as per the WHO standards. The Areas (A1, A3, A5, A7, A8, A9, A10, A12, A13\& A15) the sodium value exceed beyond the permissible limit. High concentration of sodium ion in drinking water may cause heart problems and high sodium in irrigating water may cause salinity problems (ChadrikRout.andArabinda Sharma, 2011).

\subsection{Potassium (K)}

The naturally occurring minerals in the groundwater are sodium and potassium. The potassium value of all the samples varies in the range of 2 to $92 \mathrm{mg} / \mathrm{l}$. The maximum value of potassium is obtained at the Area (A15), the minimum value of potassium was obtained at the Area (20). High amount of potassium in the groundwater sample is due to the presence of silicate minerals from igneous and metamorphic rocks (ZahirHussain and Abdul Jameel, 2011).

\subsection{Iron (Fe)}

The iron value of all the samples varies in the range of 2.8 to $0 \mathrm{mg} / \mathrm{l}$. The maximum value of iron is obtained at the Area (A15). And the minimum value of the iron is obtained at the Area (A20). The permissible limit of the iron value in the groundwater is $0.3 \mathrm{mg} / \mathrm{l}$ as per WHO standards .The Areas (A4, A6, A11, A14, A19\& A20) other than this exceeds the permissible limit.

\subsection{Manganese (Mn)}

The manganese value of all the samples varies in the range of 0 to $0.5 \mathrm{mg} / \mathrm{l}$. The maximum value of the manganese is obtained at the Areas (A3 \&A15). The minimum value of the manganese is obtained in the Areas except the Areas (A3 $\&$ A15). The permissible limit of the manganese value in the groundwater is $0.3 \mathrm{mg} / \mathrm{l}$ as per WHO standards. There is no manganese concentration in the groundwater except the Areas (A3, A15) in this analysis.

\subsection{Ammonia $\left(\mathrm{NH}_{3}\right)$}

The ammonia value of all the samples varies in the range of 0to $2.5 \mathrm{mg} / \mathrm{l}$. The maximum value of the ammonia is obtained at the Areas (A1, A10\& A15). The minimum value of the manganese is obtained in the Areas (A4, A6, A14\& A20). The permissible limit of the manganese value in the groundwateris $0.5 \mathrm{mg} / \mathrm{l}$ as per WHO standards. There is no 
manganese concentration in the groundwater at the Areas (A4, A6, A14\& A20).

\subsection{Nitrate $\left(\mathrm{NO}_{3}\right)$}

The nitrate value of all the samples varies in the range of 0 to $112 \mathrm{mg} / \mathrm{l}$. The maximum value of the ammonia is obtained at the Area (A15). The minimum value of the manganese is obtained in the Area (A20). The permissible limit of the manganese value in the groundwater is $45 \mathrm{mg} / \mathrm{l}$ as per WHO standards. The contamination of groundwater may be due to sewage and other wastes rich in nitrates (VenkateswaraRao, 2011). The presence of nitrate in groundwater may be due to leaching of nitrate with percolating powder(Mohamed Hanipha and ZahirHussian, 2013).Toxicity of nitrates in infants causes methaemoglobiaemia (US-EPA-Environment Protection Agency,2012).

\subsection{Chloride (Cl)}

The chloride value of all the samples varies in the range of 16 to $1190 \mathrm{mg} / \mathrm{l}$. The maximum value of the chloride is obtained at the Area (A15). The minimum value of the chloride is obtained in the Area (A20). The permissible limit of the chloride value in the groundwater is $250 \mathrm{mg} / \mathrm{l}$ as per WHO standards. All the Areas except the Areas (A2, A4, A6, A14, A17, A19\& A20) have higher chloride value than the permissible value. Excessive chloride in portable water is particularly but the criteria set for chloride value is based on its potentially high corrosiveness ${ }^{1}$. Soil porosity and permeability also play an important role in building up the chloride value (Jain et al., 2005).

\subsection{Fluoride (F)}

The fluoride value of all the samples varies in the range of 0.4 to $3.5 \mathrm{mg} / \mathrm{l}$. The maximum value of the fluoride is obtained at the Area (A3). The minimum value of the fluoride is obtained in the Area (A19). The permissible limit of the fluoride value in the groundwater is $1.0 \mathrm{mg} / \mathrm{l}$ as per WHO standards. All the Areas except the Areas (A2, A12, A13, A17, A18, A19\& A20) have higher fluoride value than the permissible value. The high concentration of the fluoride is due to fertilizer usage in agricultural activities for killing the insects. Skeletal fluorosis is an important disease due to presence of high fluoride content in groundwater (MangaleSapana et al., 2012).

\subsection{Sulphate $\left(\mathrm{SO}_{4}\right)$}

The sulphate value of all the samples varies in the range of 2 to $250 \mathrm{mg} / \mathrm{l}$. The maximum value of the sulphate is obtained at the Area (A15). The minimum value of the sulphate is obtained in the Area (A20). The permissible limit of the sulphate value in the groundwater is $200 \mathrm{mg} / \mathrm{l}$ as per WHO standards. The Area (A15) has higher sulphate value than the permissible value. High concentration of sulphate may cause gastro-intestinal irritation particularly when magnesium and sodium ions are also present in drinking water resources (Indrani Gupta et al., 2011).

\subsection{Phosphate $\left(\mathrm{PO}_{4}\right)$}

The phosphate value of all the samples varies in the range of 0 to $2.2 \mathrm{mg} / \mathrm{l}$. The maximum value of the phosphate is obtained at the Area (A10). The minimum value of the phosphate is obtained in the Area (A20). The permissible limit of the phosphate value in the groundwater is $0.1 \mathrm{mg} / \mathrm{l}$ as per WHO standards. All the Areas except the Areas (A4, A6, A14\& A20) have higher phosphate value than the permissible value. Normal water contains only a minimum phosphorus level because of low solubility of native phosphate minerals and the ability of soil to retain phosphate (Rajmohan and Elango, 2005).

\section{CONCLUSIONS}

About 20 samples were taken in and around Namakkal district and analyzed for Electric conductivity, total dissolved solids, $\mathrm{pH}, \mathrm{Ca}, \mathrm{Mg}, \mathrm{Na}, \mathrm{K}, \mathrm{Fe}, \mathrm{Mn}, \mathrm{NH}_{3}, \mathrm{NO}_{3}, \mathrm{Cl}$, $\mathrm{F}, \mathrm{SO}_{4}$ and $\mathrm{PO}_{4}$ using standard procedure. Based on this the Anion and Cation SUM are calculated to determine whether the groundwater is suitable for drinking purpose or not. It is found that only $49 \%$ is suitable for drinking purpose. The remaining Areas are having contaminated water greater than the permissible limit.so this Areas are constantly monitored and necessary actions should be taken for improving the groundwater quality and also the health of the people. 
Outline MAP of India

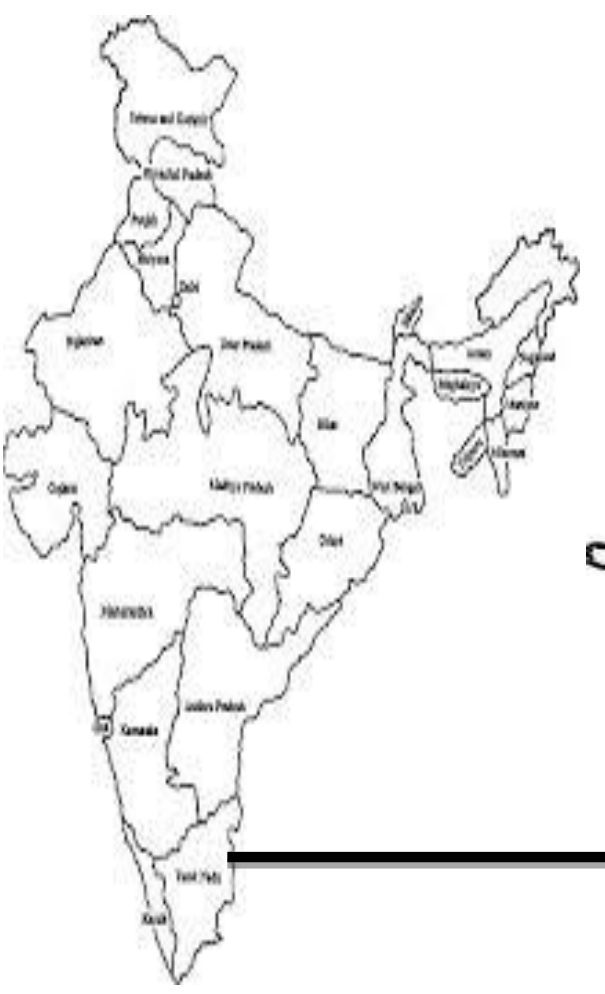

Outline MAP of Tamilnadu

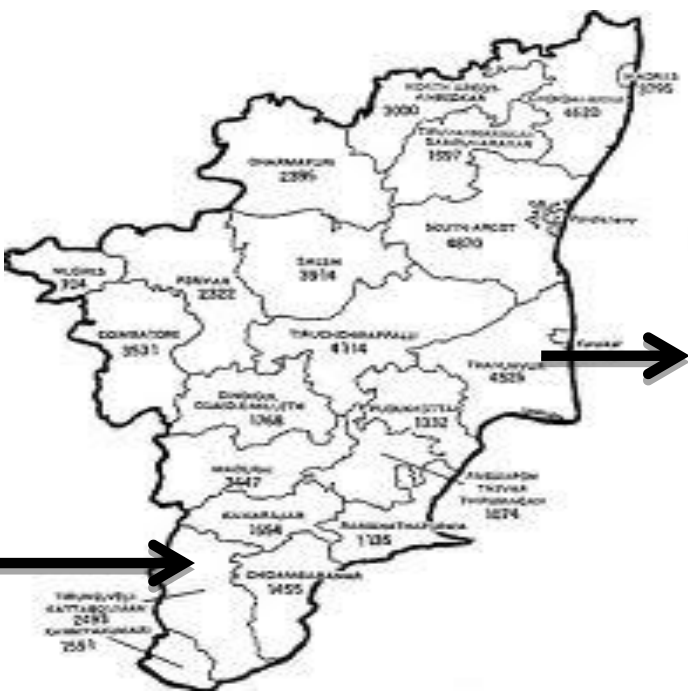

Outline MAP of Namakkal

Table-1: Physico-Chemical Characteristics of Groundwater of Namakkal District

\begin{tabular}{|c|c|c|c|c|c|c|c|c|c|c|c|c|c|c|c|c|c|c|}
\hline $\begin{array}{l}\text { Are } \\
\text { a no }\end{array}$ & EC & $\begin{array}{l}\text { TD } \\
\text { S }\end{array}$ & pH & $\begin{array}{l}\mathrm{Ca}^{2} \\
+\end{array}$ & $\begin{array}{l}\mathbf{M g}^{2} \\
+\end{array}$ & $\begin{array}{l}\mathbf{N a} \\
+\end{array}$ & $\begin{array}{l}\mathbf{K} \\
+\end{array}$ & $\mathbf{F e}^{2}$ & $\begin{array}{l}\mathbf{M} \\
\mathbf{n}\end{array}$ & $\begin{array}{l}\text { NH } \\
3\end{array}$ & $\begin{array}{l}\text { NO } \\
3\end{array}$ & $\mathrm{Cl}^{-}$ & $\mathbf{F}^{-}$ & $\mathrm{SO}_{2-}^{\mathrm{SO}_{4}}$ & $\begin{array}{l}\mathrm{PO}_{4} \\
\text { 3- }\end{array}$ & $\begin{array}{l}\text { Anio } \\
\text { n } \\
\text { sum }\end{array}$ & $\begin{array}{l}\text { Catio } \\
\text { n } \\
\text { sum }\end{array}$ & $\begin{array}{l}\mathbf{P} / \mathbf{N} \\
\mathbf{P}\end{array}$ \\
\hline$\overline{\mathrm{A} 1}$ & $\begin{array}{l}248 \\
0\end{array}$ & $\begin{array}{l}173 \\
6\end{array}$ & $\begin{array}{l}7.9 \\
8\end{array}$ & 182 & 50 & $\begin{array}{l}25 \\
4\end{array}$ & 26 & 1.8 & 0 & 2.5 & 36 & 424 & $\begin{array}{l}1 . \\
8\end{array}$ & 120 & 1.5 & 1.106 & 1.004 & NP \\
\hline A2 & $\begin{array}{l}145 \\
2 \\
\end{array}$ & $\begin{array}{l}101 \\
6 \\
\end{array}$ & $\begin{array}{l}7.3 \\
4 \\
\end{array}$ & 96 & 30 & $\begin{array}{l}15 \\
1 \\
\end{array}$ & 28 & 0.6 & 0 & 1.5 & 32 & 176 & $\begin{array}{l}0 . \\
8\end{array}$ & 52 & 1.0 & 1.036 & 1.003 & $P$ \\
\hline A3 & $\begin{array}{l}353 \\
0\end{array}$ & $\begin{array}{l}247 \\
1\end{array}$ & $\begin{array}{l}6.8 \\
9\end{array}$ & 220 & 124 & $\begin{array}{l}35 \\
9\end{array}$ & 52 & 2.5 & 0.5 & 1.6 & 86 & 624 & $\begin{array}{l}3 . \\
5\end{array}$ & 150 & 2.0 & 1.040 & 1.081 & NP \\
\hline A4 & $\begin{array}{l}124 \\
2\end{array}$ & 869 & $\begin{array}{l}7.4 \\
2 \\
\end{array}$ & 72 & 24 & $\begin{array}{l}13 \\
0 \\
\end{array}$ & 16 & 0.3 & 0 & 0 & 14 & 196 & $\begin{array}{l}2 . \\
4\end{array}$ & 24 & 0 & 0.980 & 0.938 & NP \\
\hline A5 & $\begin{array}{l}328 \\
0\end{array}$ & $\begin{array}{l}229 \\
6\end{array}$ & $\begin{array}{l}6.9 \\
8\end{array}$ & 164 & 96 & $\begin{array}{l}37 \\
8\end{array}$ & 48 & 2.2 & 0 & 2.4 & 56 & 624 & $\begin{array}{l}1 . \\
2\end{array}$ & 150 & 1.4 & 1.092 & 1.029 & NP \\
\hline A6 & $\begin{array}{l}118 \\
5\end{array}$ & 830 & $\begin{array}{l}7.4 \\
4\end{array}$ & 86 & 26 & $\begin{array}{l}12 \\
5\end{array}$ & 14 & 0.3 & 0 & 0 & 17 & 112 & $\begin{array}{l}1 . \\
2\end{array}$ & 76 & 0 & 0.977 & 1.032 & $\mathrm{P}$ \\
\hline A7 & $\begin{array}{l}259 \\
8 \\
\end{array}$ & $\begin{array}{l}181 \\
9 \\
\end{array}$ & $\begin{array}{l}7.0 \\
2 \\
\end{array}$ & 184 & 50 & $\begin{array}{l}26 \\
6 \\
\end{array}$ & 30 & 2.4 & 0 & 2.2 & 52 & 424 & $\begin{array}{l}2 . \\
2 .\end{array}$ & 90 & 1.8 & 1.073 & 0.987 & NP \\
\hline A8 & $\begin{array}{l}299 \\
0\end{array}$ & $\begin{array}{l}209 \\
3\end{array}$ & $\begin{array}{l}6.8 \\
5\end{array}$ & 224 & 60 & $\begin{array}{l}30 \\
5\end{array}$ & 34 & 1.5 & 0 & 1.5 & 68 & 524 & $\begin{array}{l}1 . \\
4\end{array}$ & 130 & 1.2 & 1.083 & 1.012 & NP \\
\hline A9 & $\begin{array}{l}331 \\
0 \\
\end{array}$ & $\begin{array}{l}231 \\
7 \\
\end{array}$ & $\begin{array}{l}7.2 \\
2 \\
\end{array}$ & 176 & 108 & $\begin{array}{l}39 \\
6 \\
\end{array}$ & 52 & 1.8 & 0 & 1.5 & 76 & 764 & $\begin{array}{l}2 . \\
6\end{array}$ & 180 & 1.2 & 1.091 & 1.095 & NP \\
\hline A10 & $\begin{array}{l}286 \\
7\end{array}$ & $\begin{array}{l}200 \\
7\end{array}$ & $\begin{array}{l}6.9 \\
8\end{array}$ & 144 & 68 & $\begin{array}{l}35 \\
6\end{array}$ & 46 & 0.5 & 0 & 2.5 & 44 & 656 & $\begin{array}{l}1 . \\
8\end{array}$ & 120 & 2.2 & 1.029 & 1.027 & NP \\
\hline A11 & $\begin{array}{l}159 \\
6\end{array}$ & $\begin{array}{l}111 \\
7\end{array}$ & $\begin{array}{l}7.4 \\
2\end{array}$ & 94 & 28 & $\begin{array}{l}16 \\
6\end{array}$ & 20 & 0.2 & 0 & 0.8 & 44 & 288 & $\begin{array}{l}1 . \\
2\end{array}$ & 68 & 0.2 & 1.093 & 0.923 & $\mathrm{P}$ \\
\hline A12 & $\begin{array}{l}206 \\
0\end{array}$ & $\begin{array}{l}144 \\
2\end{array}$ & $\begin{array}{l}7.0 \\
1\end{array}$ & 138 & 38 & $\begin{array}{l}21 \\
2\end{array}$ & 24 & 1.2 & 0 & 0.8 & 38 & 336 & $\begin{array}{l}1 . \\
0\end{array}$ & 90 & 1.0 & 1.101 & 0.964 & NP \\
\hline
\end{tabular}




\begin{tabular}{|c|c|c|c|c|c|c|c|c|c|c|c|c|c|c|c|c|c|c|}
\hline A13 & $\begin{array}{l}224 \\
0\end{array}$ & $\begin{array}{l}156 \\
8\end{array}$ & $\begin{array}{l}6.9 \\
4\end{array}$ & 144 & 42 & $\begin{array}{l}23 \\
0\end{array}$ & 26 & 0.8 & 0 & 1.5 & 42 & 340 & $\begin{array}{l}0 . \\
4\end{array}$ & 110 & 0.6 & 1.075 & 0.952 & NP \\
\hline A14 & $\begin{array}{l}122 \\
4\end{array}$ & 857 & $\begin{array}{l}7.4 \\
4\end{array}$ & 82 & 26 & $\begin{array}{l}12 \\
8\end{array}$ & 16 & 0.3 & 0 & 0 & 26 & 144 & $\begin{array}{l}1 . \\
2\end{array}$ & 56 & 0 & 1.043 & 1.000 & $P$ \\
\hline A15 & $\begin{array}{l}497 \\
0\end{array}$ & $\begin{array}{l}347 \\
9\end{array}$ & $\begin{array}{l}7.7 \\
3\end{array}$ & 292 & 168 & $\begin{array}{l}54 \\
4\end{array}$ & 92 & 2.8 & 0.5 & 2.5 & 112 & $\begin{array}{l}119 \\
0\end{array}$ & $\begin{array}{l}2 . \\
4\end{array}$ & 250 & 1.8 & 1.066 & 1.095 & $\mathrm{NP}$ \\
\hline A16 & $\begin{array}{l}190 \\
4\end{array}$ & $\begin{array}{l}133 \\
3\end{array}$ & $\begin{array}{l}7.3 \\
7\end{array}$ & 118 & 34 & $\begin{array}{l}19 \\
6\end{array}$ & 22 & 0.4 & 0 & 1.8 & 42 & 276 & $\begin{array}{l}1 . \\
2\end{array}$ & 40 & 1.5 & 1.039 & 0.934 & $\mathrm{P}$ \\
\hline A17 & $\begin{array}{l}156 \\
3\end{array}$ & $\begin{array}{l}109 \\
4\end{array}$ & $\begin{array}{l}7.8 \\
7\end{array}$ & 104 & 58 & $\begin{array}{l}12 \\
4\end{array}$ & 24 & 0.6 & 0 & 1.5 & 32 & 168 & $\begin{array}{l}1 . \\
0\end{array}$ & 72 & 1.0 & 1.087 & 1.022 & $P$ \\
\hline A18 & $\begin{array}{l}187 \\
2\end{array}$ & $\begin{array}{l}131 \\
0\end{array}$ & $\begin{array}{l}7.0 \\
6\end{array}$ & 118 & 34 & $\begin{array}{l}19 \\
3\end{array}$ & 22 & 0.6 & 0 & 1.0 & 44 & 280 & $\begin{array}{l}1 . \\
0\end{array}$ & 60 & 0.6 & 1.086 & 0.946 & $\mathrm{P}$ \\
\hline A19 & 325 & 228 & $\begin{array}{l}6.7 \\
8\end{array}$ & 20 & 12 & 30 & 2 & 0.3 & 0 & 0.4 & 3 & 32 & $\begin{array}{l}0 . \\
4\end{array}$ & 6 & 0.2 & 1.094 & 1.029 & $\mathrm{P}$ \\
\hline A20 & 124 & 87 & $\begin{array}{l}6.9 \\
6\end{array}$ & 8 & 4 & 12 & 2 & 0 & 0 & 0 & 0 & 16 & $\begin{array}{l}0 . \\
6\end{array}$ & 2 & 0 & 1.043 & 1.050 & $P$ \\
\hline
\end{tabular}

All parameters are expressed in $\mathrm{mg} / \mathrm{l}$ except $\mathrm{pH}$ and EC. EC in micro mho/cm

Table-2: Classification of Groundwater based ON TDS

\begin{tabular}{|l|l|l|}
\hline TDS mg/l & Description & No of Samples \\
\hline$\leq 1000$ & Non-saline & 5 \\
\hline $1000-3000$ & Slightly-saline & 14 \\
\hline $3000-10000$ & Moderately-saline & 1 \\
\hline$\geq 10000$ & Very-saline & 0 \\
\hline
\end{tabular}

\section{REFERENCES}

[1] Mohamed Hanipha M. and ZahirHussian A., Study of Groundwater Quality at Dindigul Town, Tamilnadu, India, international journal on environmental sciences, 2(1), 68-73, January(2013).

[2] Adewoya B.L. and Oludura A.O., Efficiency of MorignaOleifera Seeds Extract on Microflora of Surface and Groundwater, Journal of Plant Sciences, 6, 453-438 (2007).

[3] WHO, International standards for drinking water, World Health Organization, Geneva, Switzerland (1992)

[4] APHA, American Public Health Association, Standard Methods for Estimation of water and Wastewater, AWWA, Water Pollution Control Federation, New York, 19 (1995).

[5] Pradeep Jain K., Hydrology and quality of groundwater Hirapur district, Sagar (M.P), Pollution Research, 17(1), 91-94 (1998)

[6] Bhattacharya T., Chakraborty S. and Tuck Neha., Physico chemical Characterization of groundwater of Anand district, Gujarat, India, I. Res. J. Environment Sci., 1(1), 28-33 (2012)

[7] KoulNishtha, Lokhande R. S. and Dhar J. K., Physico-Chemical, Bacteriological and Pesticide analysis of Tap Water in Millennium City Gurgoan, Haryana, India, I.Res. J. Environment Sci.,1(2), 1-7 (2012)

[8] Chari K.V.R. and Lavanya M.G., Groundwater contamination in Cuddapah urban area, Andhra Pradesh, In Proceedings on regional Workshop of
Environmental aspects of groundwater development. KU, Kurukshetra Oct. 17-19, Kurukshetra, India, 130-134 (1994)

[9] Varadarajan N., Purandara B.K. and Bhism Kumar., Assessment of groundwater quality in GhataprabhaCommand area, Karnataka, India, $J$. Environ. Science and Engg.,53(3), 341-348 (2011)

[10] Chadrik Rout.AndArabinda Sharma., Assessment of drinking water quality, a case study of Ambala cantonment area, Hariyana, India, International Journal of Environmental Sciences, 2(2), 933-945 (2011)

[11] ZahirHussain A. and Abdul Jameel. M., Monitoring the quality of groundwater on the bank of Uyyakondan channel of river Cauvery at Tiruchirappalli, Tamilnadu, India, Environmental Monitoring and Assessment, 10.10007/s 10661, 011, 1910-14 (2011)

[12] VenkateswaraRao B., Physico-chemical analysis of selected groundwater samples of Vijayawada rural and urban in Krishna district, Andhra Pradesh, India, International Journal Environmental Sciences, 2(2), 710-714 (2011)

[13] Basic Information in Nitrates in Drinking Water, Basic information about Regulated Drinking WaterContaminants, US-EPA-Environment Protection Agency (2012)

[14] Jain C.K., Bhatio, K.K. and Kumar, S.R., Groundwater quality in malaprabha sub-basin Karnataka, International Journal of Environmental Protection, 23(3), 321-329 (2005) 
[15] MangaleSapana M., ChondeSonal G. and Raut P.D. Use of MoringaOleifera (Drumstick) seed as Natural Absorbent and an Antimicrobial agent for Groundwater Treatment, Res. J. Recent Sci., 1(3), 3140 (2012)

[16] Indrani Gupta., AbhaysinghSalunkhe., Nanda Rohra. and Rakesh Kumar., Groundwater quality in Maharashtra,India, Focus on Nitrate pollution, Journal of Environmental Science and Engineering, 43(4), 453-462 (2011)

[17] Rajmohan N. and Elango L., Nutrient chemistry of groundwater in an intensively irrigated region of southern India, Environmental Geology, 47, 820-830 (2005) 